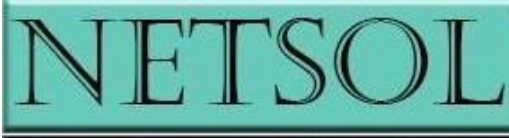

NEW TRENDS IN SOCIAL AND LIBERAL SCIENCES

An Interdisciplinary Journal

http://www.netsoljournal.net/

Volume 4, Issue 2, pp.1-23, Fall 2019

https://doi.org/10.24819/netsol2019.05

Date Submitted: March 19, 2019

Date Accepted: August 2, 2019

\title{
Is Modernity a Third Axial Age?
}

Ken Baskin, Independent Scholar

Dmitri M. Bondarenko

\section{Institute for African Studies of the Russian Academy of Sciences \& National Research University Higher School of Economics}

\begin{abstract}
In the book where he coined the term "Axial Age", Karl Jaspers noted that human history included both "tranquil ages" and "ages of change". This paper begins with the observation that this oscillation between stable and transformational periods encapsulates the pattern in complexity theory by which systems oscillate between relatively long "stable states" and shorter "phase transitions". Applying this pattern, the coauthors speculate that human history has undergone three such "axial" phase transitions - the Neolithic Revolution, the Axial Age, and Modernity. During each of these periods, the older dominant social structures proved inadequate, as populations grew, new technologies appeared, and new social conflicts became more intense. To meet these challenges, people in the societies where these transformations occurred became more innovative, exploring new ways to use recently developed technologies and introducing a variety of social experiments. By the end of these ages of change, new social structures would become dominant across Eurasia. Today, Modernity, as the third axial age, seems to be coming to an end, making this pattern a valuable tool for understanding our world.
\end{abstract}

Key Words: Axial Age, Social Breakdown, Phase Transition, Symbolic Order, Social Complexity, Modernity, Neolithic Revolution

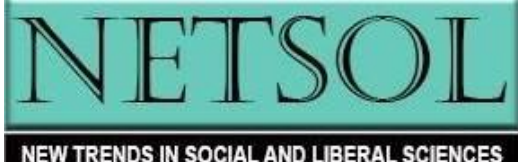


There are tranquil ages, which seem to contain that which will last for ever, and which feel themselves to be final. And there are ages of change which see upheavals that, in extreme instance, appear to go to the roots of humanity itself. Karl Jaspers, The Origin and Goal of History (1953: 231)

In these two sentences, Karl Jaspers summarizes the subject on which the coauthors of this essay have been working for a decade. We met at a workshop on "Complexity Theory and Philosophy" in Stellenbosch, South Africa, where we independently presented papers applying Complexity Theory to history (Baskin, 2007; Bondarenko, 2007). After a few conversations, we decided to apply some of the principles of Complexity Theory to the parallels we both recognized between Modernity (c. $1500 \mathrm{CE}$ to the present) and the Axial Age (c. 800 to 200 BCE). This was hardly a new idea. Jaspers (1953) mentions it in the book where he coined the term "Axial Age", and the idea of Modernity as a second axial age has been treated both as a time of religious transformation (Cousins, 1992; Lambert, 1999; Swidler and Mojzes, 2000, Armstrong, 2006), and as a total socialpolitical-economic-ideological transformation (e.g., Assmann, 2008; Landon, 2010; Bellah, 2011; Wittrock, 2012). Our contribution was to add a dimension from Complexity Theory.

What we discovered in writing our book (Baskin and Bondarenko, 2014) was that Modernity might more accurately be considered a third axial age, rather than a second. At the heart of our examination was a key pattern in Complexity Theory, the way evolving complex systems oscillate between relatively long "stable states" and shorter periods of transformation, "phase transitions" (e.g., Cohen and Stewart, 1994) - Jaspers" "tranquil ages" and "ages of change", respectively. In this way, we defined a lower case "axial age" as an historical phase transition - the extremely dynamic, innovative period during which a globally dominant social structure broke down and evolved into a social structure that would dominate the coming period. The Axial Age, for example, followed the breakdown of the early agricultural states (c. 3000-800 BCE), such as Mycenae in Greece or Zhou China, and led to the rise of the far more sophisticated agricultural empires (c. 200 BCE1500 CE), the Roman Empire or Chinese dynasties. Similarly, Modernity developed with the beginnings of the breakdown of agricultural empires and may well be leading to a more fully globalized world.

In the process of thinking through this dynamic, we also concluded that the Neolithic Revolution (c. 11,000 to 5,000 years ago) functioned as such a phase transition, during which hunter-gatherer social structure evolved through a series of intermediate socio-political organizations into the early agricultural states, such as Mesopotamia or Egypt. We began thinking of these three stable periods of human history as HunterGatherer Bands, the Pre-Axial State, and the Post-Axial State. From this point of view, the last 50 thousand years of human history presents itself as a process of adaptation to increasing social complexity, as measured, for instance, by the number of levels of overall cultural complexity and political integration, community size and the number of classes

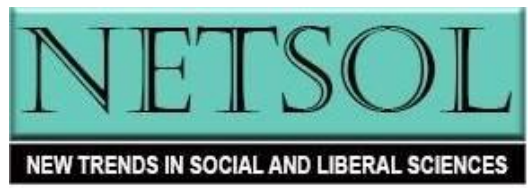


and social roles (Bondarenko, 2007), manifesting itself in alternating stable states and phase transitions.

In this paper, we want to make our case for three axial ages by examining:

- First, how Complexity Theory illuminates the idea of an axial age;

- Then, the results of viewing human history as a process of increasing social complexity; and

- Finally, the dynamics these three axial, transformational periods share.

Our purpose in writing this paper, however, goes beyond making the case for considering human history as this sort of process. Each of the transformational periods we discuss emerged to meet crises that could have overwhelmed the societies that experienced them. In the course of those transformations, people in these societies appear to have felt that they were being overwhelmed. That is certainly how people across the globe feel today, as we face challenges ranging from global warming to international terrorism and the possibility of a mass extinction. Yet our species has always found ways to survive such potentially overwhelming crises. And the perspective we present in this paper suggests that the human race may be able to survive even today's crises. With that, we turn to a look at Complexity Theory and how it illuminates the phenomena of the transformational axial ages.

\section{Complexity Theory and the Axial Phenomenon}

Complexity Theory is a cross-disciplinary field of study that examines the world in terms of the emerging scientific paradigm that is replacing the older Newtonian paradigm (e.g., Smolin, 1997; Laughlin, 2005; Baskin and Bondarenko, 2014). With the emerging paradigm, our world is a deeply interconnected nested network of energy storage systems (Ho, 2008), where every system behaves as both a functioning network and an agent in more inclusive networks. The human body, for example, is a nested network of organs in organ systems, cells in organs, and molecules and atoms in cells. At the same time, the body is a component in larger networks - from families to organizations to ecosystems. For the coauthors of this paper, Complexity Theory studies the patterns that emerge as any of these complex, networked systems evolve.

Several patterns identified in Complexity Theory are helpful in studying history. For instance, where the Newtonian paradigm examines causality in terms of linear causeand-effect, Complexity views causality as non-linear, adaptive, and systemic. That is, as agents anywhere in a system change, they can cause adaptations among other agents, which cause further adaptations until all these shifts can result in a cascade of adaptation. For example, from a Newtonian perspective, one might say that the Indulgences of the Catholic Church caused Martin Luther to nail his 95 Theses to the door of the church at Wittenberg, which precipitated a series of actions that led to the Reformation. Complexity Theory, however, views the Reformation as far more non-linear, the result of a far wider network of historical processes. Those processes include the rise of the merchant class in Western Europe, the Black Death and the way it undermined the stability of the feudal system, and the alliance between landowners and the Church whose power the growing merchant class

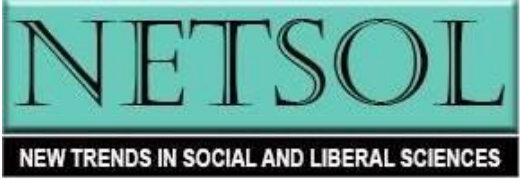


challenged by allying with Protestants. All these processes unfolded among still other processes, including the Eurasian world economic system created after the Mongol invasion of Eastern Europe in the mid-thirteenth century (Abu-Lughod, 1989) and the growth in literacy and science resulting from the printing press (Eisenstein, 2005). With a Complexity Theory perspective, we can see the Reformation, not as an inevitable causal chain, but as a sprawling series of adaptations at many levels of scale, from the mutations in the DNA of Yersinia pestis to the invention of Guttenberg and the overreaching of the House of Habsburg (Baskin and Bondarenko, 2018).

Of all the patterns identified in Complexity Theory, however, the one we found most useful was that of the life-cycle of an attractor. In Complexity Theory, an attractor is the habitual behaviors, out of all possible behaviors, which emerge as the agents in networks interact. In this way, both networks and the agents in them are drawn to certain behaviors, which become typical. ${ }^{1}$ Over time, the attractor of any evolving complex network tends to oscillate between relatively long stable states and shorter, turbulent phase transitions. One of us depicted this oscillation in this back-of-the-cocktail-napkin figure first published a decade ago (Baskin 2008):

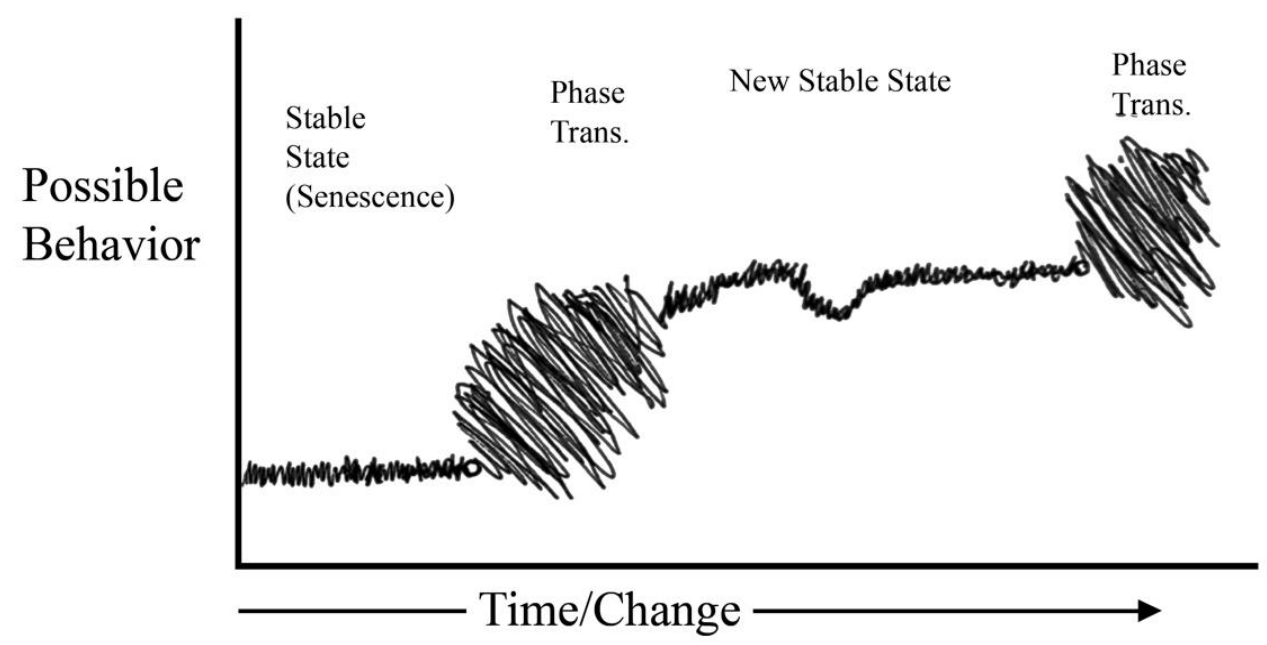

Figure 1: Life Cycle of an Attractor

The pattern is familiar: Throw a chunk of ice in a pot on a stove and turn up the heat. It will remain ice until it approaches the melting point and, then, go into a turbulent phase transition, after which it will become water. It will remain water until it approaches the boiling point, go into a turbulent phase transition, and become water vapor. It can be water in any of these three phases, but it can only be in one at any moment, depending on the conditions of its environment.

${ }^{1}$ For a fuller description, including a brief explanation of the word's origins in mathematics, see Cohen and Stewart, 1994: 204-207.

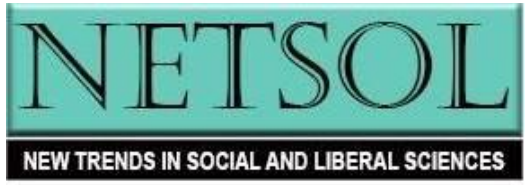


This pattern applies to almost any complex network that evolves over time, punctuated equilibrium, for example, the pattern of ecosystem evolution defined by Niles Eldredge and Stephen Jay Gould (Gould, 2002). It can also represent social processes ranging from Michel Foucault's theory of the evolution of Western culture (1994) to Giovanni Arrighi's examination of Western Capitalism (2010), from Miroslav Bárta's (2015) analysis of Ancient Egyptian history as punctuated equilibrium to Gerhard Mensch's analysis of the cycle of economic depressions and booms (1979).

A similar pattern emerges in all these social processes: When a stable state ends, the network of living agents, ideologies, and technological artifacts (Latour, 2005) within that phenomenon falls apart, and its agents begin to explore their current environment in a transformational phase transition. Those agents continue in that highly innovative period until they find patterns of behavior that enable them to survive. Over time, those patterns become attractors, the habits that define the behaviors that become characteristic of a phenomenon. Capitalism in the twenty-first century America, Christianity in twelfth century Europe, Neo-Confucianism in fifteenth century China - each of these terms describes the complex of ideas, stories, technologies and behaviors that characterized their societies.

As the environment of any phenomenon changes over time, it continues in its stable state and adapts to those changes. The longer those habits are successful, the deeper the relationships based on them become. If those habits continue to be successful long enough, people come to depend on the habits to support their sense of identity, their financial security, and the esteem of others. As a result, when the changes in the environment become so great that the old habits make it difficult, or impossible, to adapt, people find themselves locked in old behaviors because they fear what they may lose. The process then enters "senescence" (Salthe, 1993), in which its agents try to force the old habits to deal with new challenges, creating a sense of crisis. Finally, these agents are no longer able to cope, the overall network falls apart, and its components re-enter phase transition or the system falls apart.

\section{History as Evolving Attractors}

When we started discussing the similarities between the Axial Age (c. 800-200 BCE) and Modernity (c. 1500 CE-the present), we noted that both were times of:

- Rapid population growth - the number of Axial Age cities with a population of at least 100,000 grew from three to eighteen, and Modern world populations from about half a billion to more than seven billion (Modelski, 2003)

- Accelerated technological innovation - what the development of iron and writing did for the Axial Age, the machine and printing did for Modernity

- Increased socio-cultural innovation - Axial experiments in politics included the poleis in Greece and 140 monarchies in China, while in Modernity the national state emerged in its many varieties

- Devastating warfare - the Warring States Period in Axial Age China and the Peloponnesian Wars in Greece were the Axial Age equivalent of the Religious

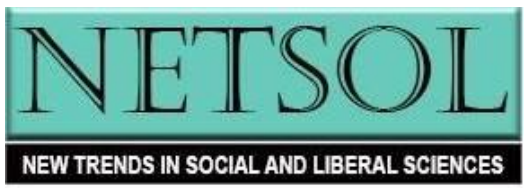


Wars of the sixteenth-seventeenth centuries and the World Wars of the twentieth in Western culture.

As we discussed how to examine these similarities, we wondered whether we could treat these periods as phase transitions in the evolution of human culture. When we did, we began to think of it as we depicted it in Fig. 2, as three stable states punctuated by three phase transitions:

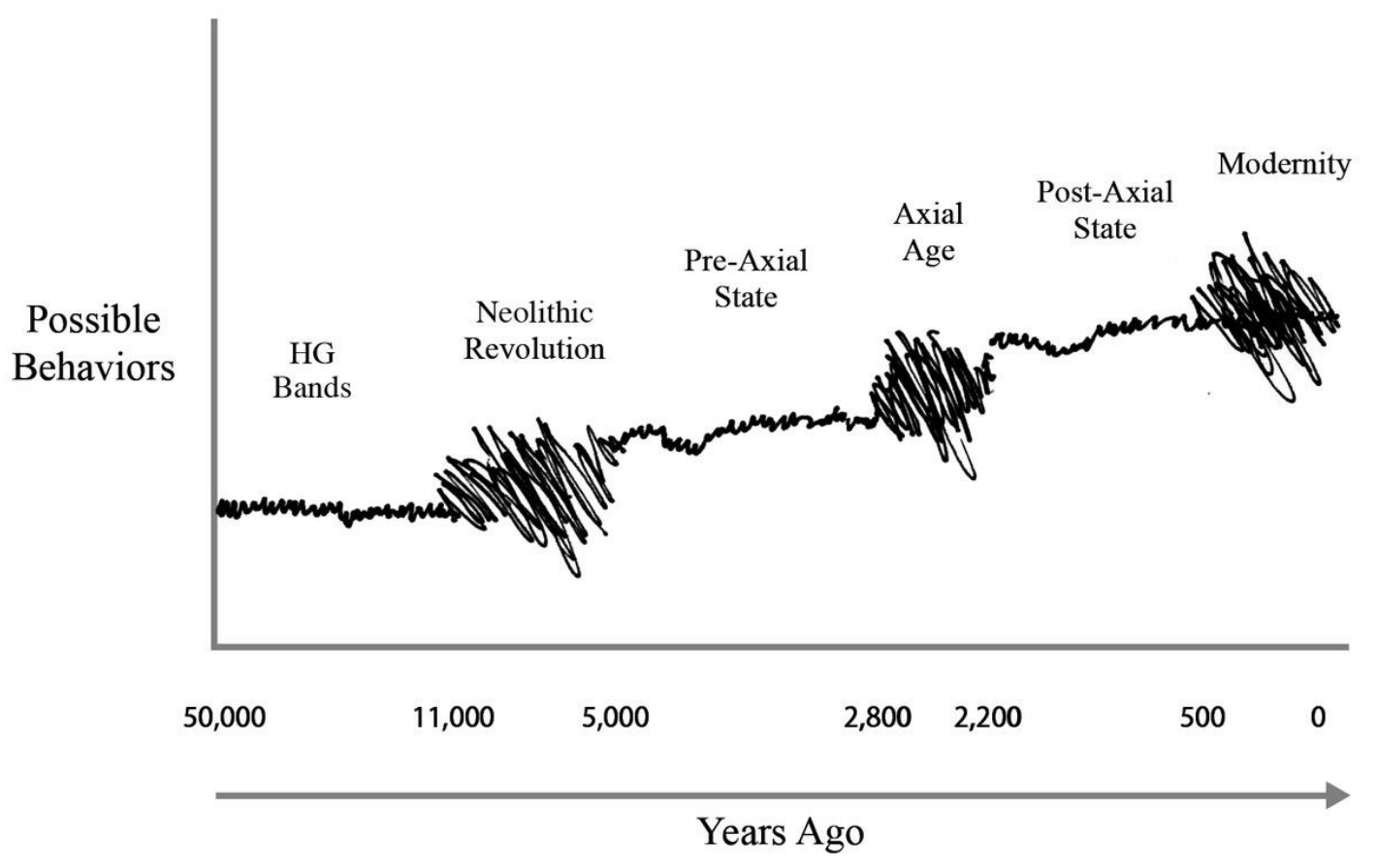

Figure 2: The Three Axial Ages (Baskin and Bondarenko, 2014) ${ }^{2}$

This figure depicts our theory of how human societies have evolved over the last fifty thousand years. During that period, we suggest, three relatively stable periods, characterized by a dominant social structure, which seems to have emerged independently in many locations, enabled people to adapt to the increasing social complexity, as communities grew from bands of 20 to cities of 20 million. Each stable period continued until conditions changed so much that its dominant social structure was overwhelmed, at which time the society went into a transformational phase transition. The point we want to emphasize, then, is that there have been three axial transformations, each enabling people

\footnotetext{
${ }^{2}$ We mean this figure to be suggestive, rather than mathematically precise. For that reason, we have left it as rough as possible. History is too messy and abundant, and what we know with certainty is too limited, to assume that events should conform to our abstractions. As a result, we have, for example, avoided making the time axis on Fig. 2 mathematically precise. Moreover, the figure is overly linear. For the most part, stable states do not simply end and phase transitions begin; rather, societies seem capable of moving back and forth between the two.
}

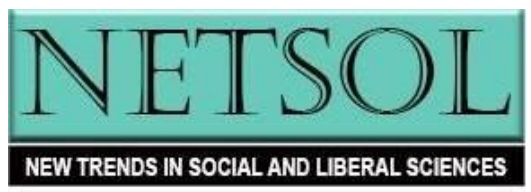


in long-standing dominant social structures to recreate their societies for the more socially complex conditions they now faced. From this point of view, one can understand human history as a process in which, as a general rule, the level of social complexity has continued to increase (Bondarenko, 2007).

While this approach to human history does seem to reflect some principles of Complexity Theory, it does leave out one key question: What is the "glue" that holds social networks together. Biological networks - from an amoeba to a chimpanzee to an ecosystem - are held together by physical structures, from cell walls and DNA to pheromones, and signs, such as group-specific songs in some species of birds (d'Aquili et al, 1979). We propose that what holds human cultural networks together is the "world stories" that encode the symbolic order that organizes any group. Such symbolic orders are essential, because they enable people in any society to interpret experience similarly, and, therefore, to cooperate in social networks ranging from families to states (Baskin, 2008; Baskin and Bondarenko, 2014). Historically, human symbolic orders have ranged from the huntergatherers' sense that they were integral parts of the environment in which they lived (Lent, 2017) to the Confucian belief that social order demanded that people conform to the oneon-one responsibilities of their social conditions (Schwartz, 1985) to the Newtonian assumption that the world is composed of distinct "things" that interact according to the laws of nature (Baskin and Bondarenko, 2014). In many ways, these shared symbolic orders, and the sophisticated language that expresses them, may be one of the most important factors that differentiates fully modern human beings from Neanderthals and early Homo sapiens (Donald, 1991; Mithen, 1996; Deacon, 1997).

The world story, a concept that we developed in our book, is the set of related mythic stories and discourses that encode the symbolic order at the heart of any society. In many ways, world stories seem to function much like Joseph Campbell's conception of myth, which provides "a field in which you can locate yourself" (2004: xvi). ${ }^{3}$ For Campbell, myth has four key functions:

1. To reconcile people to the horrors of life,

2. To understand the cosmos as both a "field" in which they "play" life's game and a set of forces to which they must respond,

3. To justify and maintain their social system, and

4. To guide them through a life time of psychological challenges.

Faced with challenges that might overwhelm any society, its mythology/world story provides the guidance for survival, sometimes in the existing stories and discourses and sometimes in creating new ones that can help them adapt to unexpected challenges.

We use "world story" rather than "mythology" because, starting in the Axial Age, the use of writing for cultural purposes (Assmann, 2011) allowed philosophy and preWestern science to fulfill some key functions of myth. So, while before the Axial Age, any society's world story was largely identical to its mythology, by the end of the Axial Age, the world stories of some cultures also included elements of science and philosophy. The

${ }^{3}$ While it is tempting to examine the issue of myth at this point, we have limited our discussion to Campbell, who focuses on the key functions that myth most fully shares with world stories.

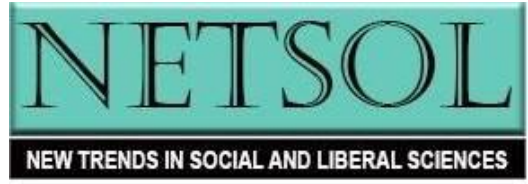


Chinese world story, for example, is highly philosophical (Schwarz, 1985); the Greek world story, both philosophical and scientific (Martin, 1996); and Indian religion, highly philosophical (Obeyesekere, 2012). In Modernity, science began to take over the central position that religion had occupied (Campbell, 2004; also Gaukroger, 2006). Such world stories are not merely "religious"; their combination of myth and discourse integrates spiritual concerns with social, economic and political matters.

As a general rule, we found that any society's world story and the behavior it drives form a positive feedback loop. As long as a society's circumstances do not shift radically, its explanations of the forces that challenge the society produce behavior that enables people to meet those challenges, validating its world story and reinforcing the habits that become its cultural attractor. However, when circumstances shift radically, the old habits a world story encourages can become an obstacle to social survival. Then, a new world story must emerge through the process depicted in Fig. 2. These transformations are the phase transitions, and in some cases the "axial ages", of human history. We now turn to a discussion of these periods of rapid, radical transformation.

\section{Three Axial Periods}

In the rest of this paper, we'd like to give a quick overview of what we believe to be the dynamics of the three axial periods of human history. Because researchers know relatively little about the Neolithic Revolution (Scott, 2017), we want to start with the Axial Age and Modernity, both reasonably well-documented, in order to define the patterns we see in these transformations. With those patterns in hand, we will then proceed to the Neolithic Revolution, and, taking advantage of what is currently believed about the period, explain why we think of this period as another example of a radical axial transformation.

\section{The Axial Age (c. 800-200 BCE)}

Starting about 1200 BCE, new developments across Eurasia began to overwhelm the great Pre-Axial States that had dominated the Eastern Mediterranean, India, and China. All these states maintained themselves with a similar social structure - a sacral king responsible for the ritual duties that ensured prosperity, who depended on the loyalty of his inner circle and a polytheistic religion. This social structure had proven enormously successful, as these states became vastly wealthier with cities that grew from 40,000 in Uruk c. 3300 BCE to 160,000 in Egypt's Pi-Ramses c. 1200 BCE (Modelski, 2003: 22, 33). Moreover, advances in technology transformed social conditions: Widespread writing began changing the way people understood their societies (Assmann, 2011), and warfare became more intense, with cheaper, more plentiful iron weapons, and the horses and chariots that made it possible to conquer empires (Anthony, 2007). These were exactly the kinds of changes Complexity Theory suggests would overwhelm the social structure of the Pre-Axial State.

Then a series of events began to break down the states that would experience Axial Age transformation. Beginning around $1175 \mathrm{BCE}$, a series of well-developed societies dissolved. Mycenae, the Hittites, Ugarit were all destroyed, although the reason or reasons remain largely unclear, attributed sometimes to natural catastrophe, to political instability,

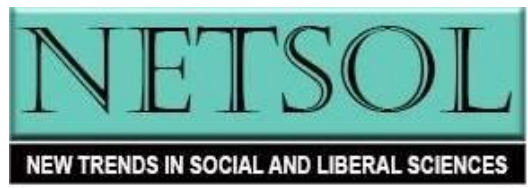


or to the invasion of "Sea People" (Cline, 2014). Aryan migrations continued to transform portions of India through c. 1000 BCE. In China, the Zhou dynasty began losing control of its territories by the middle of the tenth century BCE. And in the late eighth century, Assyria destroyed Israel and besieged Jerusalem in Judah. The Axial Age had begun. And with it came a period of thorough social transformation, in which these societies struggled to meet the forces that threatened to overwhelm them (Assmann, 2008; Wittrock, 2012).

The key dynamic in these transformations concerns the interplay between their world stories and the experiences that resulted from them. As Assmann (2011) points out, all four societies (Greece, India, China, and Israel) began with a "foundational text", the written reinterpretation of their old mythology. Each then took the guidance of these mythologies into their early Axial Age experiences. Over time, these experiences would lead to changes in their way of seeing the world and an accepted textual "canon" articulating a new world story for their more complex world. And after those canons were completed, each would create "commentary" to their world stories as they struggled with their still transforming societies. ${ }^{4}$ Given the space limitations of this paper, we can only offer a quick overview of one Axial Age experience, that of Greece.

After the collapse of Mycenae early in the twelfth century BCE, the Greek world entered a "dark age" in which cities had been abandoned (e.g., Bellah, 2011). By the eighth century, some cities were beginning to recover, and the early Greek Axial Age world story began in the retelling of the earlier Greek mythology in the poetry of Hesiod and the epics of Homer (late eighth/early seventh centuries BCE). The works of both Hesiod and Homer suggest a world where the powerful forces represented by the Greek gods can at any time push society into chaos, as in the story of the Titan Cronus castrating his father Uranus, or the casual way a meaningless beauty contest between Athena, Hera, and Aphrodite precipitates a decade-long war. While this tenuous balance between chaos and order was typical of most pre-Axial Age mythology, it is possible that some of the fear of chaos one sees in both Hesiod and Homer also reflects the absence of central political power in the centuries after the collapse of Mycenae. In any case, the political structures and the culture of honor one finds in Homer's epics seem to have provided the order early Axial Age Greece needed, until the beginning of the fifth century BCE.

The Iliad gives us an especially interesting illustration of the dynamics between a society's world story and its subsequent experience. In it, Homer depicted the aristocracies of the small Greek societies - Mycenae, Sparta, and Ithaca, for example - as a fractious brotherhood, coming together to protect each other's honor, going to war over Helen, and defeating the enemy from the east, Troy. Afterward, they returned home and continued to fight like feuding brothers. This appears to have been the Greek world story in 490 and 480 BCE, when Persia attacked with its far-larger armies. Like Homer's small Greek societies, the poleis cooperated to defeat the Persian enemy from the east. However, in the decades that followed, without an eastern enemy to unite them, Athens and Sparta fought like the

\footnotetext{
${ }^{4}$ It makes sense to accept Assmann's ideas of canon and commentary as at least somewhat metaphorical. While the Bible of the Israelites had a formally approved canon, the canon of Greece, China, or India was defined far more informally, as was the "canon" of Modernity.
}

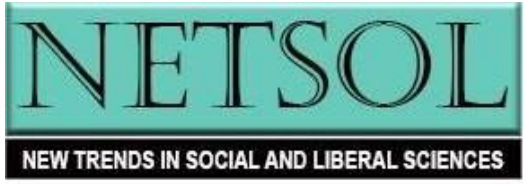


aristocrats of the Homeric epics, leading to the Peloponnesian War (431-404 BCE), the demise of the power of the Greek poleis, and the rise of Macedonia. To what extent did the world story of the Iliad and Odyssey shape these events? It would be reckless to claim direct causality, but the parallels suggest more than coincidence.

During Greece's turbulent fifth century BCE, its society entered the second phase of Assmann's transformation process, "canonization", creating a new world story for the transforming society. While the process of canonization was not as formal as that of the Hebrew Bible, which was occurring at roughly the same time, the works that made up the new world story emerged over time (e.g., Armstrong, 2006; Bellah, 2011). Athenian society captured the terror of that period especially well in the tragedies of Aeschylus (c. 525-c. 456), Sophocles (c. 495-c. 404), and Euripides (c. 485-c. 407), which appeared from roughly 472 BCE (Aeshculus' The Persians) to 404 (Euripides' The Bacchae). In those tragedies, essentially good people, such as Orestes or Oedipus, are caught up in powerful forces, ranging from the social obligations of Agamemnon and Oedipus to the irrationality of Clytemnestra and Medea, and subjected to an almost unbearable amount of suffering.

If the tragedies depict the forces that challenged the Greek poleis during the Axial Age, then, the Greek mix of philosophy and science, culminating in the work of Plato (c. 427-c. 347) and Aristotle (384-322), offered a way to confront those forces and restore order to society, what Jeremy Lent (2017) calls "the deification of reason". Plato would draw on two centuries of Greek science and pre-Socratic philosophy to create an ideal of rational behavior and governance in order to tame the chaos. For example, Plato insists in Timaeus that the order and rationality of the cosmos had to be the product of a mind outside our world, his divine craftsman, the Demiurge. Moreover, Plato's Demiurge was a mathematician, who employed geometry to construct the world (Lindberg, 2007). This order is most evident in the realm of Forms, of which our everyday world is only an imperfect reflection. For Plato, most people are unable to see this truth, because they are caught in the illusions he illustrated in the Parable of the Cave. As a result, he recommended abandoning the guidance of art - Hesiod and Homer, Aeschylus and Sophocles - replacing these thinkers with Socrates (Bellah, 2011). In The Republic, he set a curriculum for the "philosopher kings" who would be able to govern with the clarity they derived from studying mathematics and living abstemious lives. To create an orderly world, he suggests, one needs truly virtuous men who are able to control the passions that so often lead to chaos (Lent, 2017).

The works of Aristotle would complete the canon of Greece's new world story, applying Plato's idealization of reason in many practical ways. For Aristotle, the world was "an orderly, organized world, a world of purpose, in which things developed toward ends determined by their natures" (Lindberg, 2007: 52). As his cosmology indicates, chaos is not a quality of the Universe. The Heavens reflect crystal perfection. Only our sublunary world exhibits a sometimes-chaotic, ever-changing spectacle. And humans create chaos largely because they were not guided by the pure intellect of the divine. Aristotle's practical application of Greek rationalism included works on subjects ranging from the nature of tragedy to natural philosophy in physics and biology, from metaphysics to ethics. In this

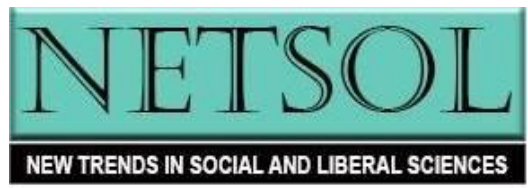


way, Aristotle would "sketch out most of the fields of inquiry that would preoccupy later thinkers" (Bellah, 2011: 395).

The problem with a written canon - as opposed to a pre-literate oral tradition - is that it makes changing with shifting circumstances far more difficult. To do so, the Axial Age societies would engage in what Assmann (2011) calls "commentary", additional writings that carry the authority of the canon, but make new approaches to new challenges possible. In Greece, that work included the writings of thinkers, such as the Stoics and Epicureans, the Cynics and Neo-Platonists in the Hellenistic period, and Roman thinkers such as Marcus Aurelius. And Aristotle's work in natural philosophy would be expanded and reinterpreted by figures such as Ptolemy, who mapped the movements of the heavens; Eratosthenes, who drew the first world map on a grid of longitude and latitude; and Aristarchus, who used geometry to estimate Earth's size (Freely, 2012).

Over the course of about half a millennium, this process of transformation would produce the understanding of the world that supported the Roman Empire and would eventually combine with the Jewish tradition to produce Christianity. Processes with a remarkably similar dynamics would play themselves out in Israel, India, and China (e.g., Armstrong, 2006; Bellah, 2012).

\section{Modernity (c. 1500-the present)}

One reason we wrote The Axial Ages of World History was to test the intuition we shared that Modernity and the Axial Age played out in similar processes. If that intuition were valid, we should be able to understand the beginnings of Modernity as a product of the same dynamics that we found in Axial Age Greece. That was what we found. Like the social collapse and intense warfare that overwhelmed Axial Greece, a variety of forces overwhelmed Late Medieval Europe:

- the Mongol economic world-system (1250-1350), stimulating rapid growth of the Western European merchant class

- the Black Death (1346-51), which shattered the stable feudal social structure

- the discovery of the New World and the inflow of information from China and Muslim countries

- the growing wealth that led to the corruption at the heart of Martin Luther's protest

- the century and a half of religious war that would terrify all of Western Europe as Christians butchered each other over the proper way to worship the Prince of Peace.

As with the Greek experience, this sense of being overwhelmed would supercharge Western Europe's ability to transform itself.

One major difference between the Axial Age and modern transformations is that, while the dynamics in all four Axial Age locations were similar, they occurred separately. With Modernity, however, the transformation started in one place, Western Europe, and spread across the globe. As Shmuel Eisenstadt describes these "multiple modernities", "[T]he best way to understand the contemporary world - indeed to explain the history of modernity - is to see it as a story of continual constitution and reconstitution of a multiplicity of cultural programs", so that "modernity and Westernization are not identical"

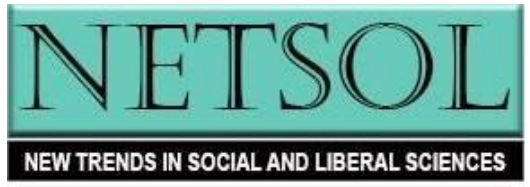


(2017: 2). Yet we also agree with him that "Western patterns of modernity . . . enjoy historical precedence and continue to be a basic reference point for others" (Eisenstadt, 2017: 2-3). The rise of the West began with the emergence of capitalism and the beginning of trade and territorial expansion in the fifteenth century, and by the end of the nineteenth century, Western powers had largely imposed their culture - and many of their values, at least at a superficial level - on the rest of the world, setting the stage for the more tightly integrated globalization occurring today. So, Modernity by no means became equal to Westernization, but at the same time the West set the socio-cultural agenda for most parts of the world for several centuries ahead. Probably, only now are we witnessing the final stages of that trend. In this way, Western Modernity has dominated the very discourse of Modernity in general as a set of multiple modernities.

The foundational texts of Modernity would emerge from the mythology and theology of Late Medieval Christianity, just as the texts of Homer and Hesiod did from the oral mythology of pre-Axial Age Greece. Two Christian themes would be central to the world story that would guide the West's transformation. First, the scientific world story would draw on the theological position that nature was the purposeful creation of a loving God, a "second book" from which man could come to know God (e.g., Gaukroger, 2006) and seek dominion over all other living things (Genesis 1:26). That world story would also draw on the popular Christian myth of the Quest for the Holy Grail. In this myth, the salvation of society can only be achieved through the success of King Arthur's quest knights, who are willing to sacrifice their lives to serve their king.

These two elements of Late Medieval Christianity would find their way to the heart of the early Modern foundational texts, as presented in its philosophy, especially the work of Francis Bacon (1561-1626) and René Descartes (1595-1650). Like the Greek canon, Modernity's foundational texts were primarily philosophical. Bacon criticized the speculative methods of medieval thinkers, arguing, instead, for what Gillespie (2009: 37) calls "a total reconstruction of science, the arts, and human knowledge". Bacon wanted to know what Nature was and how it worked. As a result, he promoted science as a quest by a new type of quest knight, the scientist, whose job was to torture nature in order to make it reveal its secrets. Through such procedures, he wanted to discover nature's hidden powers and master them for the benefit of man and the salvation of society. Like Bacon, Descartes wanted mankind to use science to master an unruly and dangerous world, eliminating poverty and providing security. To achieve those ends, Descartes wanted to create a science of certainty through mathematics, which would enable the scientist to escape the distortions of the senses. By analyzing complex events in the world into their component elements, he believed, scientists would be able to understand the laws by which God moved matter (e.g., Gaukroger, 2006). For Descartes, doing so was possible because God was loving and reasonable, and would never deceive man. As a result, science would be able to fully explain God's world and how to perfect it (Gillespie, 2009). This philosophy would sit at the heart of the early modern worldview, as a way to return order to a society that had descended into the chaos of war and unremitting change.

The philosophy of Bacon and Descartes would articulate and support the conception of science that figures, such as Galileo and Newton were developing. As

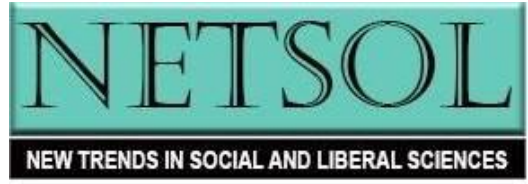


scientific quest knights, they would demonstrate the power of controlled observation and mathematically modeling the objects they studied, discovering not only new worlds, such as the moons of Jupiter, but a new way of knowing the world and its powerful forces (Wootton, 2015). Early modern science unfolded from thousands of years of earlier science - from Ancient Greece, China, India, Jews, and Islam (e.g., Lindberg, 2007; Freely, 2012) - creating a backlog of knowledge without which early modern science would have been impossible. But now science was developing the canon for a world story, in Newton's Principia Mathematica (1687), for example, with a radical new way of understanding and adapting to the potentially overwhelming forces which they had to address. By the turn of the eighteenth century, the canon of the Modern world story was in place, as much in the activities of the Royal Society and its dedication to the principles of Western science as in the writings of the scientists and philosophers who established it.

This scientific world story is often referred to as the "Newtonian" paradigm, and it provided an excellent methodology for addressing a century and a half in which "people had been killing each other in the name of truth. . . "Now the emerging world story was giving them science, which was not so much about providing an explanation as "reliable prediction in the form of a mathematical model" (Wootton, 2015: 424; 393). The God depicted in this world had created the universe using mathematics. That world must therefore be clear, rational, and deterministic (Berman, 1981). It must be open to human perception and understanding. The perfect metaphor for this world was the clock, and it was composed of distinct, separate "things" that interact according to nature's invariable laws, creating chains of cause-and-effect. As a result, "If, at a particular instant, you knew the position and velocities of every object in the universe, along with all the forces on them, you could theoretically predict their complex behavior forever" (Halpern, 2015: 13). The task of the scientist, then, was to study the world objectively in the search for the immutable laws of nature that would enable human beings to control the world and save mankind from unnecessary suffering, as Bacon and Descartes had suggested.

For roughly the next two and a half centuries, thinkers would provide the commentary on this world story, much as Hellenistic thinkers had for the world story of Plato and Aristotle. The results of this process were often remarkable. The Industrial Revolution made it possible for larger and larger numbers of people to live free from poverty; life spans increased as a result of better sanitation and the medical science that bloomed in the early twentieth century; and the increasing amount of scientific knowledge created a self-reinforcing cycle of learning about the world. At the same time, all this activity brought a series of unexpected consequences with it. Developments in a series of fields, including the work of Pierre-Simon de Laplace in astronomy, Charles Lyell in geology, Jean-Baptiste de Lamarck, Karl von Baer, and especially Alfred Wallace and Charles Darwin in biological evolution, destroyed the authority of the Bible's narrative as the way the Earth and the life on it came into being; the research of Michael Faraday (17911867) and James Clerk Maxwell (1831-1879) in electromagnetic fields revealed the weaknesses in Newton's physics; and the discoveries of Albert Einstein (1879-1955) and the quantum physicists finally uncovered the many ways the Newtonian world story was inaccurate. At the same time, evidence grew that this world story was also causing effects

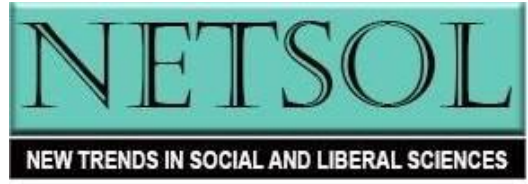


that were damaging people, societies, and the Earth itself. Forces such as ecological spoliation, terrorism, nuclear proliferation, and global warming now threaten to overwhelm mankind. As a result, a new line of commentary of the modern world story has emerged that, if we are fortunate, may allow our species to address those forces (Laughlin, 2005; Smolin, 2013; Lent, 2017).

For the study of society, Giambattista Vico (1668-1744) did what Descartes and Newton did for natural sciences: In Scienza Nuova (The New Science, 1725), he represented the social world and human history as completely dependent on objective laws that make history a predetermined, unilinear, predictable and rationally explainable process. This view found further development in disciplines such as sociology and social anthropology, which emerged in the early-mid nineteenth centuries. Rigorous positivism, anticlericalism, and conviction in undeniably unilinear progressive pathway of mankind characterized thinking and writings of such intellectual giants of the time as Karl Marx (1818-1883), Auguste Comte (1798-1857), Herbert Spencer (1820-1903), Edward Tylor (1832-1917), Henry Maine (1822-1888) and others.

While the differences between the way the transformations of the Axial Age and Modernity are significant, we are convinced that their essential dynamics are parallel and that it makes sense to examine them as two illustrations of the same transformational historical phenomenon. We now turn to the question of whether the Neolithic Revolution conforms to the dynamics of the Axial Age and Modernity.

\section{The Neolithic Revolution (c. 11,000-5,000 years ago)}

In some ways, the Neolithic Revolution is unique. For one thing, it lasted approximately six thousand years, nearly ten times longer than the Axial Age or Modernity. For another, it was pre-literate, and without any texts, its events could not strictly conform to Assmann's three-part model of the dynamics of such transformational periods. For still another, the nature of the existential threats to the old social structure were far more intense - ranging from creating an entirely new way of governing society, the state, to adapting to the epidemic diseases that emerged with livestock domestication. Moreover, as James Scott (2017) points out, hunter-gatherers almost surely mounted significant resistance to the "human" domestication of being forced into a farming style of living. So it is possible to argue that the Neolithic Revolution was a fundamentally different type of social transformation from those of the Axial Age and Modernity.

Yet, even with these differences, we are convinced that the Neolithic Revolution is best understood as the first, and the most challenging, of human history's axial periods. Our conviction begins with the nature of the existential threats that human groups faced in the millennia following the end of the Ice Age. For roughly 200,000 years, Homo sapiens had lived in nomadic hunter-gatherer bands, following the herds they hunted or scavenged and gathering the seasonal fruit and vegetables along the path of their travels. These bands consisted of about 20-30 individuals and often gathered for festivals in mega-bands of up to about 250 (e.g., Dunbar, 2016).

Anthropologists generally accept that these bands were largely egalitarian, if only because, as nomads, it would have been difficult to accumulate wealth. To maintain that

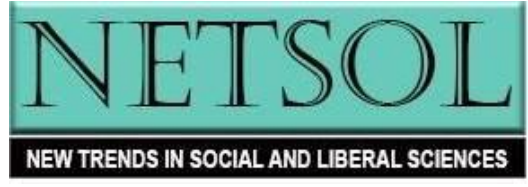


egalitarianism, these groups apparently remained largely self-organizing, putting intense social pressure on members who tried to become more powerful. They might have leaders in critical times, as when they went to war, but such leadership was generally temporary (Bellah, 2011). However, primatologists have observed the division of non-human primates into largely egalitarian and clearly non-egalitarian groupings (e.g., Vehrencamp, 1983; Matsumura, 1999; Butovskaya et al., 2000), so hierarchy seems to be deeply rooted in human prehistory. Anthropologists have also observed both egalitarian and nonegalitarian cultures among the simplest non-specialized hunter-gatherers - for example, the egalitarian Hadza, San, and Pygmies of Africa, North American Shoshone, South Asian Paliyans, Yukaghirs of Siberia, etc. vs. the non-egalitarian Australian aborigines, Tasmanians, Ona of Terra del Fuego, Athapaskans and Eyak of North Pacific Rim, or the Lower Amur Nanais. The archaeological and historical-anthropological evidence confirms the deep antiquity of non-egalitarian simple human cultures; so it seems likely that not only egalitarianism but also non-egalitarianism has characterized human cultures since the deepest archaeological past (see Bondarenko, 2006: 16-17).

The hunter-gatherers of the Neolithic Revolution had a wide range of knowledge about the areas, as well as the flora and fauna through which they moved. Moreover, their lives were "orchestrated by a host of natural rhythms of which they [had to be] keen observers" (Scott, 2017: 89). They were, in short, crucially dependent on these rhythms, and the critical challenge they faced was living in harmony with the complex ecosystems through which they traveled. To meet that challenge, their world story depicted all the elements of their surroundings as "related parts of a dynamic, integrated whole" (Lent, 2017: 84). And they seemed to experience the Earth as their giving parents. In addition, they appear to have revered their ancestors, who were often thought of as spirits, whose needs they fulfilled in order to ensure the success of their communities, although they did not worship their ancestors, but, rather, interacted with them as participants in the community (Bellah, 2011). This style of living remained our species' dominant social structure until the end of the Ice Age, c. 11,000 years ago. By that time, a sophisticated symbolic world had emerged, as demonstrated in the cave art in sites such as Lescaux in what's now southwestern France (Wunn and Grojnowski, 2016).

The end of the Ice Age brought warmer and wetter weather, and, communities began growing to hundreds and then thousands. They were able to do so because of the abundance in fish, game, and vegetable life caused by the climate change (Scott, 2017). Initially, these communities continued the foraging economies that hunter-gatherers had developed. At Lepenski Vir, on the Danube River between Romania and Serbia, for example, a large, year-around community took advantage of sturgeon migrations and plentiful game about 8,500 years ago (Fagan, 2010). But even at that time, the early domestication of grains and some animals had begun in the Fertile Crescent, where protocities, such as Jericho, began to emerge 9,500 years ago. About 9,000 years ago, one early city supported by farming, Çatal Höyük, in southern Anatolia, is estimated to have had a population as large as 5,000 (Modelski, 2003). Over the several millennia, the resulting farming economy would spread across the globe from its sources in Anatolia, China, and the Americas.

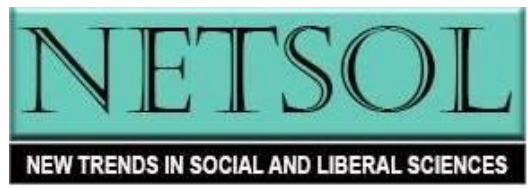


The combination of larger communities and an agricultural style of life would overwhelm the social structure of the hunter-gatherer band, much as the forces that drove the Axial Age and Modernity overwhelmed the pre-Axial states and post-Axial empires respectively. On one hand, people now found themselves living in communities far too large to know everyone they dealt with. As a result, the social pressure that had enabled hunter-gatherers to control the behavior of others was no longer effective. And as we have seen, the desire for control in a chaotic world has been a factor in all these axial periods. On the other, because these larger groups were sedentary - and because they now had access to abundant resources - it became possible for some families and even individuals to consider pieces of land "their" property and to become wealthy and more powerful.

With the addition of agriculture, another set of challenges emerged, because the style of living was so different. Farmers generally had to work longer and harder than hunter-gatherers; their diet was more limited and less healthy; and close contact with farm animals created epidemic diseases (Scott, 2017). On the other hand, John Romer notes, farmers were able to "manipulate some of [the] same natural processes [they had observed as hunter-gatherers]. By their very labour, they were redefining the universe in which they lived and their place within it" (2012: 35). With the surpluses farming enabled, they would build the more socially complex societies that would emerge as a result of the Neolithic Revolution (Simmons, 2007: 121-174).

If the theory we have been developing in this essay is valid, the tensions created by these new realities would have driven a transformation of the hunter-gatherer world story. To produce that transformation, the Neolithic Revolution should have been a time of mythic innovation, shaping the world story that would evolve into the dominant social structure of the Pre-Axial State. Such innovations could not be written down, because fully effective writing systems did not appear until sometime around 3000 BCE (Fischer, 1999). The first true mythic text would not appear until the twenty-fourth century BCE (Morrow, 2015), with the Pyramid Texts in the pyramid of Pharaoh Unas (2350-2325 BCE). And religious writings did not become widespread until the Axial Age. As a result, much of what anthropologists believe about the transformation of the Neolithic Revolution's world story is speculative, combining what they have learned about contemporary huntergatherers, tribal people, and chiefdoms (e.g., Bellah, 2011) and archaeological research over the last several decades, which has provided a rich collection of evidence, suggests the sort of mythic transformation we have been discussing.

As we noted, because writing did not exist, it is impossible to use Assmann's threestep template to examine how the hunter-gatherer world story became that of the pre-Axial states. However, one mythic image - the "Primordial Mother" in the Mediterranean basin and the Middle East - can give us a feeling for how its meaning evolved, both shaping and being shaped by powerful forces that some of the transforming societies experienced. We focus the rest of our discussion on that experience, despite the controversies around interpretation of this image among archaeologists and other specialists (see, e.g., Hodder and Meskell, 2010: 23; Wesler, 2012: 65-66). These images begin with the naked "Venus figurines" that appeared perhaps 40,000 years ago, among hunter-gatherers, as an already complex symbol. On one hand, they present their genitals aggressively, much as other

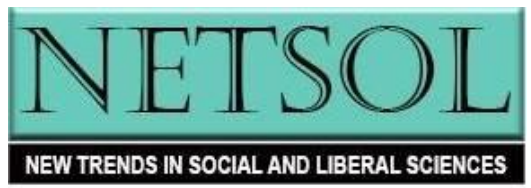


primates do; on the other, their oversized breasts symbolize nurturing (Wunn and Grojnowski, 2016). In this way, the Primordial Mother can be both protector of the hearth and the mother of both physical and spiritual life (Campbell, 2013). At this point, she appears not to be a figure for worships so much as a way of thinking about the forces of the world and the way people lived.

With the introduction of agriculture, as at Çatal Höyük, her meaning seems to have evolved. In some statues, the presenting woman figure would become what Campbell calls the "Goddess-as-transformer", the image of Nature in a farming society, as she "receives the seed of the past and, through the miracle of her body, transmutes it into the life of the future" (2013: 25). In other statues, she also represents death (e.g., Hodder and Meskell, 2010; Wunn and Grojnowski, 2016). This figure would later develop, in many societies, into the ruler of the Underworld. From her hunter-gatherer image as Primordial Mother, she has now transformed into "the root of this whole mythology of the Goddess in her two aspects as She who takes the seed and transmute it into life, and She who eats back the body and brings it forth renewed" (Campbell, 2013: 31). Finally, with the emergence of an elite class, she would become a goddess of myth, as with Isis in Egypt or Persephone in Greece.

One of the key elements of this transformation occurred between 3500 and 3000 BCE, in the cities of Sumer and Egypt. These communities had developed a class structure, with a priestly class, a governing class, a merchant class, and servant and farmers. That class structure demanded a mythology that could make sense of this social complexity. Moreover, the priestly class had developed the early mathematics and astronomy needed to maximize agricultural production. With this knowledge, mythology transformed into cosmology, offering the image of an orderly cosmos that was reflected in the society's social structure, thereby explaining the roles of all classes (Barber and Barber, 2004). At the same time, the Primordial Goddess became the Cosmic Goddess, Inanna in Sumer and Isis in Egypt. For Campbell (2013: 73), the Cosmic Goddess represented "the mystery of the continuous creation" that people in these agricultural communities experienced. And the success of those cultures, as well as those in other pre-Axial states in India, China, and the Americas, offers testimony to the power of the feedback loop of changing circumstances, shifting world stories, adaptive behavior, and the unfolding of further new circumstances.

Our brief discussion of the evolution of the Goddess image only begins to examine the path of world-story evolution during the Neolithic Revolution. However, it does suggest that the dynamic we found in the Axial Age and Modernity transformations seems very like that of this earlier transformation. And, so, we conclude that human history has, in fact, experience three such periods of axial transformation.

\section{Conclusion}

Why are the ideas we have sketched out in this essay important? First of all, we do not present the periodization of human history as "punctuated equilibrium" as a replacement for other models, but, rather as a provocative tool for students of history. For example, Marx's economic model is a valuable way of thinking about history in terms of

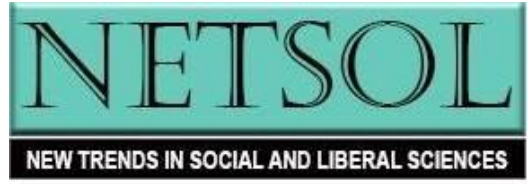


the stages of foraging, agricultural production, and industrial/technological production (see Grinin, 2012). We present our model as a complement to others, offering a deeper look into the complexities of social transformation and a deeper appreciation of the role of the myth and other discourses that make up what we are calling a world story. It might be profitable, then, to explore how these models can illuminate each other.

What may be even more important, however, is the way these ideas can redirect the way people are thinking about the challenges the world community faces today. Those challenges range from addressing terrorism and global warming to overcoming nationalized tribalism in a globalized world economy and feeding a world population that may reach ten billion. Like the problems faced in the Neolithic Revolution and the Axial Age, these challenges resulted from people's best efforts to adapt to their own age's increases in social complexity, threatening to overwhelm us today, just as the emergence of large cities threatened to overwhelm people toward the end of the Neolithic Revolution or horrific war technology threatened to overwhelm them toward the end of the Axial Age. In each case, some communities were able to develop world stories that enabled them to survive - even thrive - as they addressed those challenges.

But, some thinkers might reply, today is different. Challenges such as global warming or feeding a population of ten billion really are overwhelming. Surveying the political quagmire we find across the globe, it is simply impossible to imagine implementing effective solutions to our problems, even if we had those solutions at hand. In many ways, this sort of despair is the greatest challenge we face.

Our response, drawn largely from the ideas we have presented here, is this: Throughout human history, our species has faced challenges that threatened our survival. And because people in any time and place are so deeply embedded in their world stories, a way to meet those challenges often seemed unimaginable. For example, if we could talk with people in a hunter-gatherer band 30,000 years ago and tell them that people would one day live in communities of 20 million, their responses might be something like, "That's impossible. Human nature would not allow it." Yet, we have learned to live in such communities. What is unimaginable today can unfold in the richness of time, and it does so, we believe, in the process of innovation that we have presented in this paper.

If we have overcome such challenges in the past, we can, at least, hope that we shall do so again. And studies like our own may actually contribute to the new thinking that could create the solutions that we cannot see today, including solutions to the problems we still cannot foresee.

Acknowledgements: The authors are grateful to Prof. Andrey Korotayev from the National Research University Higher School of Economics for his insightful comments on 'The Neolithic Revolution' section.

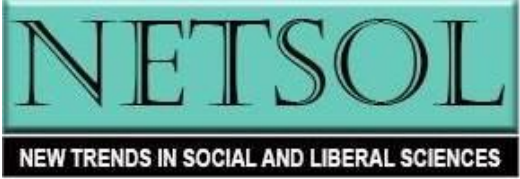




\section{References}

Abu-Lughod, J.L. (1989), Before European Hegemony: The World System A.D. 12501350. Oxford: Oxford University Press.

Anthony, D.W. (2007), The Horse, the Wheel and Language: How Bronze-age Riders from the Eurasian Steppes Shaped the Modern World. Princeton, NJ: Princeton University Press.

Armstrong, K. (2006), The Great Transformation: The Beginning of Our Religious Traditions. New York: Knopf.

Arrighi, G. (2010), The Long Twentieth Century: Money, Power and the Origins of Our Times. New York: Verso.

Assmann, J. (2002), The Mind of Egypt: History and Meaning in the Time of the Pharaohs, Jenkins, A. (trans.). Cambridge, MA: Harvard University Press.

Assmann, J. (2008), Of God and Gods: Egypt, Israel, and the Rise of Monotheism. Madison, WI: University of Wisconsin Press.

Assmann, J. (2011), Culture, Memory and Early Civilization: Writing, Remembrance, and Political Imagination. New York: Cambridge University Press.

Barber, E.W. and Barber, P.T. (2005), When They Severed Earth from Sky: How the Human Mind Shapes Myth. Princeton, NJ: Princeton University Press.

Bárta, M. (2015), "Egyptian History as an Example of Punctuated Equilibrium: An Outline", in Der Manuelian, P. and Schneider, T. (eds.), Towards a New History for the Egyptian Old Kingdom: Perspectives on the Pyramid Age, pp. 1-17. Leiden: Brill.

Baskin, K. (2007), "Foucault, Complexity, and Myth: Toward a Complexity-based Approach to Social Evolution (a.k.a. History)", in Richardson, K.A. and Cilliers, P. (eds.), Explorations in Complexity Thinking: Pre-Proceedings of the $3^{\text {rd }}$ International Workshop on Complexity and Philosophy, pp. 1-13. Mansfield, MA: ISCE Publishing.

Baskin, K. (2008), "Complexity, Foucault, and History as Evolution”, Social Evolution and History 7(2): 3-25.

Baskin, K. and Bondarenko, D.M. (2014), The Axial Ages of World History: Lessons for the $21^{\text {st }}$ Century. Litchfield Park, AZ: Emergent Publications.

Baskin, K. and Bondarenko, D.M. (2018), "History and the Process Paradigm", Presentation, 2018 International Big History Conference, July 27, in Villanova, PA, USA.

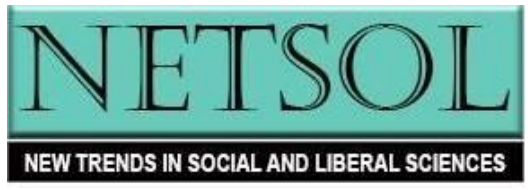


Bellah, R.N. (2011), Religion in Human Evolution: From the Paleolithic to the Axial Age. Cambridge, MA: The Belknap Press.

Berman, M. (1981), The Reenchantment of the World. Ithaca, NY: Cornell University Press.

Bondarenko, D.M. (2006), Homoarchy: A Principle of Culture's Organization. The $13^{\text {th }}$ 19th Centuries Benin Kingdom as a Non-state Supercomplex Society. Moscow: KomKniga.

Bondarenko, D.M. (2007), "What is There in a Word?: Heterarchy, Homoarchy, and the Difference in Understanding 'Complexity' in the Social Sciences and Complexity Studies”, in Richardson, K.A. and Cilliers, P. (eds.), Explorations in Complexity Thinking: Pre-Proceedings of the $3^{\text {rd }}$ International Workshop on Complexity and Philosophy, pp. 35-47. Mansfield, MA: ISCE Publishing.

Butovskaya, M.L., Korotayev, A.V., and Kazankov, A.A. (2000), "Variabilité des relations sociales chez les primates humains et non humains: a la recherche d'un paradigme general". Primatologie 3: 319-363.

Campbell, J. (2004), Pathways to Bliss. Novato, CA: New World Library.

Campbell, J. (2013), Goddesses: Mysteries of the Feminine Divine. Novato, CA: New World Library.

Cline, E.H. (2014), 1177 B.C.: The Year Civilization Collapsed. Princeton, NJ: Princeton University Press.

Cohen, J. and Stewart, I. (1994), The Collapse of Chaos: Discovering Simplicity in a Complex World. New York: Penguin Books.

Cousins E.H. (1992), Christ of the Twenty-First Century. Rockport: Element.

D’Aquili, E.G., Laughlin, C.D., and McManus, J. (1979). The Spectrum of Ritual: A Biogenetic Structural Analysis. New York: Columbia University Press.

Deacon, T.W. (1997), The Symbolic Species: The Coevolution of Language and the Brain. New York: W.W. Norton \& Co.

Donald, M. (1991), Origins of the Mind: Three Stages in the Evolution of Culture and Cognition. Cambridge, MA: Harvard University Press.

Dunbar, R. (2016), Human Evolution: Our Brains and Behavior. Oxford: Oxford University Press.

Eisenstadt, S.N. (1982), “The Axial Age: The Emergence of Transcendental Vision and the Rise of Cerics", Archives européennes de sociologie 23(2): 294-314.

Eisenstadt, S.N. (2017), "Multiple Modernities", in Eisenstadt, S.N. (ed.), Multiple Modernities. London: Routledge, pp. 1-29.

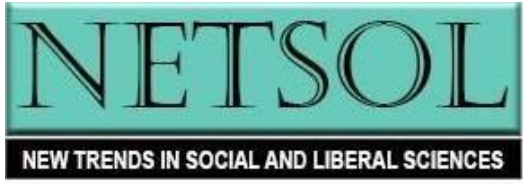


Eisenstein, E.L. (2005), The Printing Revolution in Early Modern Europe, $2^{\text {nd }}$ ed., Cambridge: Cambridge University Press.

Fagan, B. (2010), Cro-magnon: How the Ice Age Gave Birth to the First Modern Humans. New York: Bloomsbury Press.

Fischer, S.R. (1999), A History of Language. London: Reaktion Books.

Foucault, M. (1994), The Order of Things: An Archaeology of the Human Sciences. New York: Vintage Books.

Freely, J. (2012), Before Galileo: The Birth of Modern Science in Medieval Europe. New York: Overlook Duckworth.

Gaukroger, S. (2006), The Emergence of a Scientific Culture: Science and the Shaping of Modernity 1210-1685. Oxford: Oxford University Press.

Gillespie, M.A. (2009), The Theological Origins of Modernity. Chicago, IL: University of Chicago Press.

Gould, S.J. (2002), The Structure of Evolutionary Theory. London: The Belknap Press.

Grinin, L.F. (2012), Macrohistory and Globalization. Volgograd: “Uchitel” Publishing House.

Halpern, P. (2015), Einstein's Dice and Schrödinger's Cat: How Two Great Minds Battled Quantum Randomness to Create a Unified Theory of Physics. New York: Basic Books.

Ho, M.W. (2008), The Rainbow and the Worm: The Physics of Organisms. Singapore: World Scientific Publishing Co.

Hodder, I. (2010), "Probing Religion at Çatalhöyük: An Interdisciplinary Experiment", in Hodder, I. (ed.), Religion in the Emergence of Civilization: Çatalhöyök as a Case Study. Cambridge: Cambridge University Press, pp. 1-31.

Hodder, I., and Meskell, L. (2010), "The Symbolism of Çatalhöyük in Its Regional Context", in Hodder, I. (ed.), Religion in the Emergence of Civilization: Çatalhöyök as a Case Study. Cambridge: Cambridge University Press, pp. 32-72.

Jaspers, K. (1953), The Origins and Goal of History. New Haven, CN: Yale University Press.

Lambert, Y. (1999), "Religion in Modernity as a New Axial Age: Secularization or New Religious Forms?” Sociology of Religion 60(3): 303-333.

Landon, J.C. (2010), World History and the Eonic Effect: Civilization, Darwinism, and Theories of Evolution. Oregon, IL: Quality Books.

Latour, B. (2005), Reassembling the Social: An Introduction to Actor-Network-Theory. Oxford: Oxford University Press.

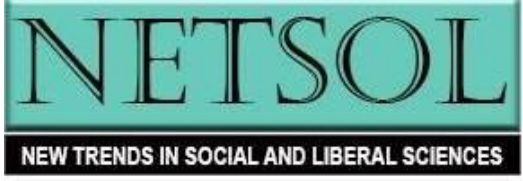


Latour B. (2015), Facing Gaia: Eight Lectures on the New Climatic Regime. Cambridge: Polity Press.

Laughlin R.B. (2005), A Different Universe: Reinventing Physics from the Bottom Down. New York: Basic Books.

Lent, J. (2017), The Patterning Instinct: A Cultural History of Humanity's Search for Meaning. New York: Prometheus Books.

Lindberg, D.C. (2007). The Beginnings of Western Science: The European Scientific Tradition in Philosophical, Religious and Institutional Context, Prehistory to A.D. 1450. Chicago, IL: University of Chicago Press.

Martin, T.R. (1996), Ancient Greece: From Prehistoric to Hellenistic Times. New Haven, CT: Yale University Press.

Matsumura, S. (1999), "The Evolution of "Egalitarian" and "Despotic" Social Systems among Macaques", Primates 43: 23-31.

Mensch, G.O. (1979), Stalemate in Technology: Innovations Overcome the Depression. Cambridge, MA: Ballinger Publishing Co.

Mithen, S. (1996), The Prehistory of the Mind: The Cognitive Origins of Art and Science. London: Thames and Hudson.

Modelski, G. (2003), World Cities, 3000 to 2000. Washington, DC: Faros 2000.

Morrow, S.B. (2015), The Dawning Moon of the Mind: Unlocking the Pyramid Texts. New York: Farrar, Straus and Giroux.

Obeyesekere, G. (2012), “The Buddha's Meditative Trance: Visionary Knowledge, Aphoristic Thinking, and Axial Age Rationality in early Buddhism", in The Axial Age and Its Consequence, Bellah, R.N. and Joas, H. (eds.). Cambridge, MA: The Belknap Press.

Romer, J. (2012), A History of Ancient Egypt: From the First Farmers to the Great Pyramid. New York: St. Martin's Press.

Salthe, S. (1993), Development and Evolution: Complexity and Change in Biology. Cambridge, MA: The MIT Press.

Schwartz, B.I. (1985), The World of Thought in Ancient China. London: The Belknap Press.

Scott, J.C. (2017), Against the Grain: A Deep History of the Earliest States. New Haven, CT: Yale University Press.

Simmons, A.H. (2007), The Neolithic Revolution in the Near East: Transforming the Human Landscape. Tucson, AZ: The University of Arizona Press.

Smolin, L. (1997), The Life of the Cosmos. New York: Oxford University Press.

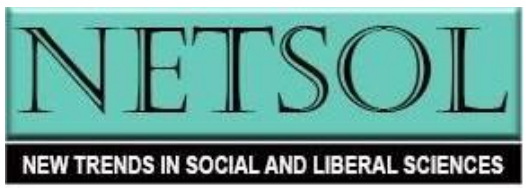


Swidler, L. and Mojzes, P. (2000), The Study of Religion in an Age of Global Dialogue. Philadelphia: Temple University Press.

Vehrencamp, S.L. (1983), "A Model for the Evolution of Despotic versus Egalitarian Societies", Animal Behavior 31: 667-682.

Wesler, K.W. (2012), An Archaeology of Religion. New York: University Press of America.

Wittrock, B. (2012), “The Axial Age in Global History: Cultural Crystallizations and Society Transformations", in Bellah, R.N. and Joas, H. (eds.), The Axial Age and Its Consequences. Cambridge, MA: The Belknap Press.

Wootton, D. (2015), The Invention of Science: A New History of the Scientific Revolution. New York: Harper Perennial.

Wunn, I. and Grojnowski, D. (2016), Ancestors, Territoriality, and Gods: A Natural History of Religion. Berlin: Springer Nature.

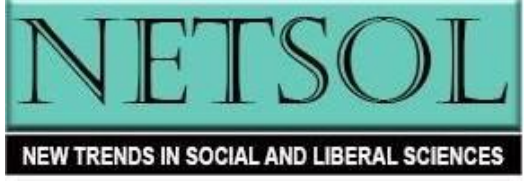

